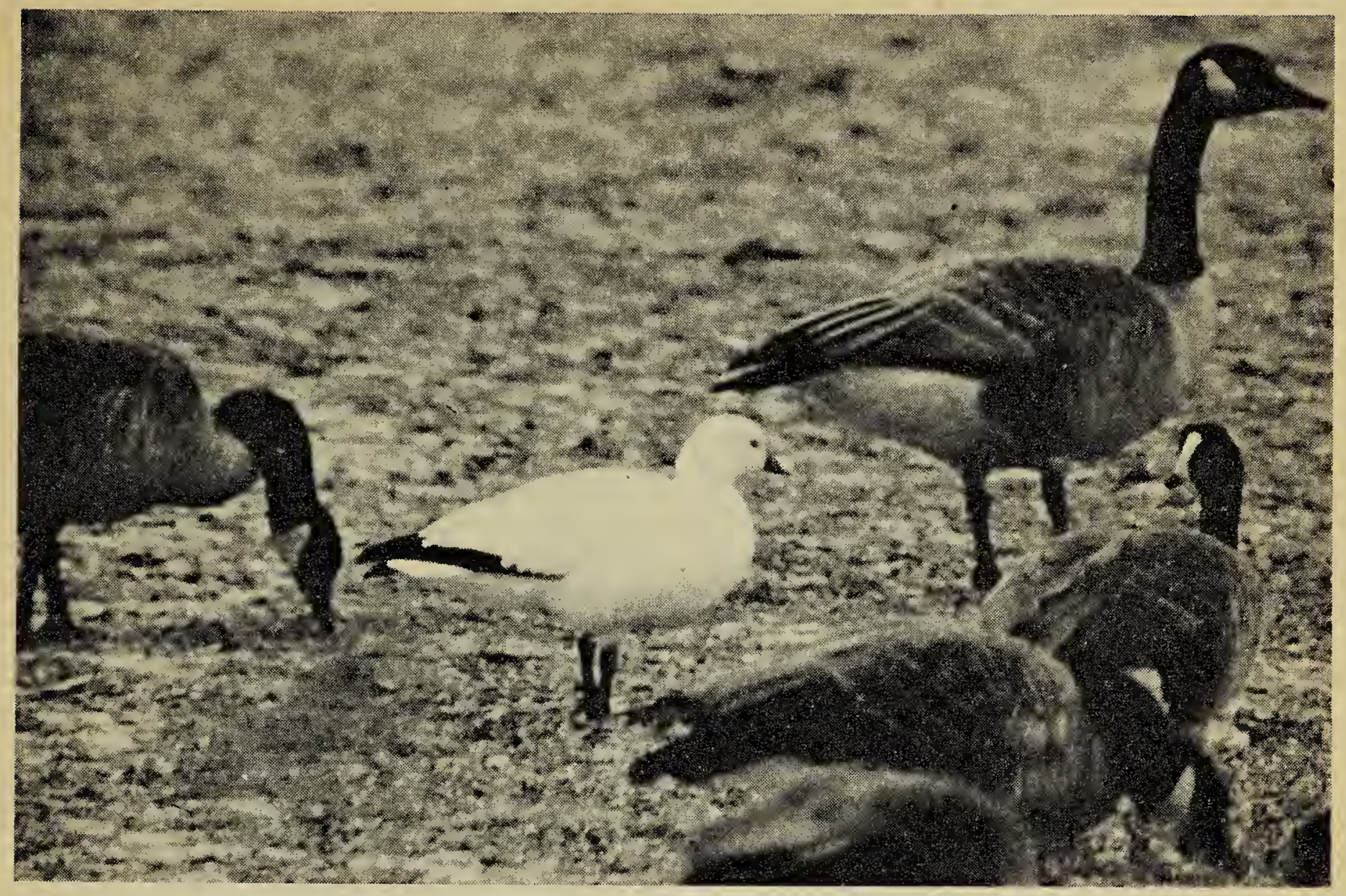

Ross' Goose at Wascana Lake, Regina

Photo by F. W. Lahrman

\section{ROSS' GEESE AT LAST MOUNTAIN LAKE}

I was fortunate enough this year to be employed by the Canadian Wildlife Service on their Sandhill Crane study at the north end of Last Mountain Lake during part of August and September. On September 13 when Dr. J. B. Millar of the C.W.S. and I were driving down the central point which projects two miles south into the north end of the lake (about nine miles west of Hatfield) we noticed some white geese on the water. Looking through the $20 x$ scope, we counted 45 Snow Geese and 24 Ross' Geese in company with 11 Canada Geese and 115 White-fronted Geese. Dr. Millar pointed out the smaller size of the Ross' Goose as compared to the Snow Goose. I returned to the same place on September 15 and counted 15 Ross' Geese and six Snow Geese. Through the $20 \mathrm{x}$ scope, I could see that the Ross' Geese were only slightly larger than the Mallards which were with them. We saw small flocks of Ross' Geese almost every day until we left on September 20._George Chopping, Dubuc, Sask.

EDITOR'S NOTE: Alex Dzubin, wildlife biologist with the Canadian Wildlife Service, reports that Ross' Goose has been a regular fall migrant, in small numbers, in the Kindersley area. However, in 1960 and 1961 , they have increased considerably, with over 1,000 individuals being present in the area at one time. Chopping's record is as far east as any recards tor Saskatchewan that we know of, except in the Regina area. Margaret Belcher (1961. Birds of Regina) reports one shot six miles from Regina on September 12, 1955, and we have two records for this fall (1961): a single Ross' Goose, identified by F. W. Lahrman, was seen on Wascana Lake and Marsh from September 29 to October 11, and three were sighted at Buck Lake, 20 miles south of Regina, by Fred Lahrman on October 8 .

\section{INTERESTING FEEDING BEHAVIOUR OF THE HOUSE SPARROW}

This past summer I was very surprised to observe House Sparrows picking dead insects from the grills and radiators of parked cars. My first observation of this was in Battleford where I flushed two birds, either adult females or immatures, from inside the grill of my automobile. Later in Saskatoon, I found this method of feeding very common among the parked cars in the downtown section. Grasshoppers, it appeared, were the main insects consumed. - William J. Merrilees, Vancouver, B.C.

EDITOR'S NOTE: This habit has previously attracted ccinsiderable atterition in ornithological literature. 